\title{
HUBUNGAN ANTARA MINAT MEMBACA DENGAN KETERAMPILAN MENULIS CERITA PENDEK SISWA KELAS V SD GUGUS VII MENGWITAHUN AJARAN 2017/2018
}

\author{
Dewa Ayu. Putri Pratiwi ${ }^{1}$, M.G Rini Kristiantari ${ }^{2}$, Ni Nym. Ganing ${ }^{3}$ \\ 1,2,3 Jurusan Pendidikan Guru Sekolah Dasar, Universitas Pendidikan Ganesha, Singaraja, \\ Indonesia \\ e-mail : dewaayuputripratiwi@yahoo.co.id ${ }^{1}$, riniokanegara@gmail.com², ninyoman.ganing@gmail.com ${ }^{3}$
}

\begin{abstract}
Abstrak
Penelitian ini bertujuan untuk mengetahui hubungan yang signifikan antara minat membaca dengan keterampilan menulis cerita pendek siswa kelas V SD Gugus VII Mengwi tahun ajaran 2017/2018. Jenis penelitian ini adalah penelitian ex post facto, korelasional. Populasi dari penelitian ini adalah seluruh siswa kelas V SD Negeri yang ada di Gugus VII Mengwi tahun ajaran 2017/2018 yang berjumlah 186 orang siswa. Penentuan sampel menggunakan teknik proportional random sampling dengan taraf kesalahan 5\% sehingga diperoleh banyaknya sampel dari populasi adalah 123 orang siswa. Data minat membaca dikumpulkan dengan memberikan angket (kuesioner) kepada sampel penelitian, sedangkan data keterampilan menulis cerita pendek didapat melalui tes uraian. Sebagai uji prasyarat adalah uji normalitas sebaran data. Setelah uji prasyarat terpenuhi, dan data berdistribusi normal analisis statistik yang digunakan dalam penelitian ini adalah teknik analisis korelasi product moment. Berdasarkan hasil analisis data di peroleh $r_{x y}$ hitung $=0,480$, sedangkan pada taraf signifikansi $5 \%$ dengan $n=123$, maka diperoleh nilai $r_{x y}$ tabel $=0,176$. Karena $r_{x y}$ hitung $>r_{x y}$ tabel, maka hipotesis nol $\left(\mathrm{H}_{0}\right)$ yang menyatakan tidak terdapat hubungan yang signifikan antara minat membaca dengan keterampilan menulis cerita pendek siswa kelas V SD Gugus VII Mengwi tahun ajaran 2017/2018 ditolak dan hipotesis alternatif $\left(\mathrm{H}_{\mathrm{a}}\right)$ diterima. Jadi, dapat disimpulkan bahwa terdapat hubungan yang signifikan dengan tingkat hubungan yang lemah dan terjadi dalam bentuk positif antara minat membaca dengan keterampilan menulis cerita pendek siswa kelas V SD Gugus VII Mengwi tahun ajaran 2017/2018.
\end{abstract}

Kata-kata kunci: minat membaca, keterampilan menulis cerita pendek

\begin{abstract}
This research aims to determine the significant relationship between reading interest with the skills of short story writing of $5^{\text {th }}$ grade students of elementary school in Gugus VII Mengwi, academic year 2017/2018. This research was ex pos facto, correlational research. The population of this research was the entire $5^{\text {th }}$ grade elementary students in Gugus VII Mengwi academic year 2017/2018 which amounted to 186 students. Sample determinated using proportional random sampling technique with 5\% error rate so that the number of samples obtained from the population was 123 students. Interest reading data was collected by giving a questionnaire to the research sample, while the data of short story writing skill was obtained from the description test. As a prerequisite test was the normality test of data distribution. After the prerequisite test is met, and the normal distributed data statistical analysis used in this research was the product moment correlation analysis technique. Based on data analysis obtained $t_{\text {hitung }}=0,480$, while at $5 \%$ significant level with $n=123$, then the value obtained $t_{\text {tabel }}$ $=0,176$. Because $t_{\text {hitung }}>t_{\text {tabe }}$ l then the null hypothesis $(\mathrm{HO})$ that states there is no significant relationship between reading interest whit the skills of short story writing of $5^{\text {th }}$ grade students of elementary school in Gugus VII Mengwi academic year 2017/2018 rejected and the alternative hypothesis (Ha) accepted. In conclusion, there was a significant relationship with a weak level relationships and occurred in the form of a positive relationship between reading interest with short story writing skill of $5^{\text {th }}$ grade students of elementary school in Gugus VII Mengwi academic year 2017/2018.
\end{abstract}

Keywords: reading interest, short story writing skill

\section{Pendahuluan}

Bahasa merupakan alat komunikasi yang berupa sistem lambang bunyi yang dihasilkan alat ucap manusia. Bahasa juga dapat diartikan sebagai alat untuk berinterak-si atau alat untuk berkomunikasi, dalam arti alat untuk menyampaikan pikiran, gagasan, konsep atau perasaan. Bahasa terdiri atas kata-kata atau kumpulan kata. Masingmasing 
mempunyai makna, yaitu hubungan abstrak antara kata sebagai lambang dan objek atau konsep yang diwakili kumpulan kata atau kosakata oleh ahli bahasa disusun secara alfabetis, atau menurut urutan abjad, disertai penjelasan dan kemudian dibukukan menjadi sebuah kamus. Secara sederhana, bahasa dapat diartikan sebagai alat untuk menyampaikan sesuatu yang terlintas di dalam hati.

Yanuarita (2014: Vol.2) menyebutkan bahwa keterampilan berbahasa mencakup empat komponen yang tidak dapat dipisah-kan yaitu keterampilan menyimak, keterampi-lan berbicara, keterampilan membaca, dan keterampilan menulis. Siswa dalam menguasai empat keterampilan berbahasa dilalui se-cara bertahap. Tahap pertama, siswa dilatih untuk terampil mendengarkan, diantaranya yaitu mampu memahami bunyi bahasa, mam-pu memahami perintah, mampu memahami cerita dan mampu memahami pengumuman. Tahap kedua, siswa dilatih untuk terampil berbicara, diantaranya meliputi kemampuan mendeskripsikan tempat, mengungkapkan pi-kiran, perasaan, kegiatan tanya jawab, percakapan, dan memberi tanggapan. Tahap ke-tiga, siswa dilatih untuk terampil membaca yaitu meliputi memahami isi teks bacaan. Tahap keempat, siswa dilatih terampil menu-lis, diantaranya meliputi kemampuan menulis permulaan, mendeskripsikan benda, menulis surat, dan mengarang.

Semua keterampilan berbahasa me-miliki peranan yang sangat penting dalam kehidupan manusia. Melalui bahasa orang dapat melakukan komunikasi, memberi dan menerima informasi, dan berbagi pengala-man kepada orang lain. Seperti juga dengan keterampilan berbahasa yang lain, keteram-pilan menulis memiliki banyak manfaat.Menu-lis selain berfungsi sebagai alat komunikasi tidak langsung juga bisa melatih seseorang untuk berpikir kritis, menggali potensi diri, dan membantu mengingat informasi. Menulis menjadi sarana bagi seseorang mengekspresikan segala emosi, pikiran dan perasaan yang sedang dirasakan oleh seseorang yang pada akhirnya dengan menulis bisa membantu seseorang menjernihkan pikiran. Menulis meru-pakan keterampilan yang paling sulit diantara keempat keterampilan bahasa yang lain. Pernyataan tersebut sebagaimana pendapat Nurgiyantoro (2012: 422) yang mengatakan dibandingkan tiga kompetensi berbahasa yang lain, kompetensi menulis secara umum boleh dikatakan lebih sulit dikuasai.

Dalman (2016 : 3), meyatakan bahwa menulis merupakan "suatu kegiatan komunikasi berupa penyampaian pesan secara ter-tulis kepada pihak lain dengan menggunakan bahasa tulis". Dalam kegiatan menulis ini, penulis harus terampil memanfaatkan struktur bahasa dan kosakata. Keterampilan menulis ini tidak datang secara otomatis, tetapi harus melalui latihan dan praktik yang teratur. Keterampilan menulis di sekolah diwujudkan melalui pembelajaran bahasa Indonesia. Menurut Kurikulum Tingkat Satuan Pendidi-kan, salah satu tujuan pembelajaran bahasa Indonesia adalah agar peserta didik mampu berkomunikasi secara efektif dan efisien sesuai dengan etika yang berlaku, baik secara lisan maupun tertulis. Adapun salah satu standar kompetensi bahasa Indonesia untuk kelas V SD adalah mengungkapkan pikiran, perasaan, dan informasi secara tertulis dalam bentuk karangan, pengumuman, dan pantun anak. Berdasarkan standar kompetensi tersebut, peserta didik mampu mengungkapkan pikiran, perasaan dan infor-masi secara tertulis yang salah satunya berbentuk tulisan cerita pendek. Tarigan (2008:3) menjelaskan dalam kegiatan menu-lis, penulis haruslah memanfaatkan grafologi, struktur bahasa, dan kosa kata. Hal ini berarti seorang penulis dituntut untuk memiliki intelektual yang cukup tinggi. Penulis harus memahami struktur dan unsur kebahasaan, menguasai kosakata, memiliki kemampuan untuk menata dan mengorganisasikan ide secara runtut dan logis, serta menyajikan dalam ragam bahasa tulis sesuai kaidah penulisan yang sedang berlaku.

Hardianto (2011: Vol.7) memaparkan bahwa membaca adalah "salah satu aktivitas belajar yang efektif untuk mendapatkan ilmu dan pengetahuan". Hal ini berarti membaca merupakan proses berpikir untuk memahami isi teks bacaan. Al-Qarni (2005:128) memaparkan bahwa membaca membantumengem-bangkan pemikiran dan menjernihkan cara berpikir, meningkatkan pengetahuan sese-orang, serta meningkatkan memori dan pemahaman. Dengan sering membaca, orang bisa menguasai banyak kata dan berbagai tipe model kalimat. Membaca sepertimengumpulkan memori, semakin banyak membaca kita seperti memiliki memori kolektif, semakin banyak wawasan yang menjadi modal menulis. 
Dari beberapa penjelasan di atas dapat diketahui pentingnya membaca untuk memudahkan seseorang dalam menulis.

Menulis dengan membaca merupakan suatu aktivitas berbahasa ragam tulis. Menulis adalah kegiatan berbahasa yang bersifat produktif, sedangkan membaca adalah kegiatan berbahasa yang bersifat reseptif(Dalman,2016:10). Seorang penulis menyampaikan gagasan, pikiran, perasaan atau informasi dalam bentuk tulisan. Sebaliknya seorang pembaca mencoba memahami gagasan, pi-kiran, perasaan atau informasi yang disajikan dalam bentuk tulisan. Membaca dan menulis merupakan suatu kegiatan yang menjadikan penulis sebagai pembaca dan pembaca se-bagai penulis. Seseorang mampu menulis setelah membaca karya orang lain atau seca-ra tidak langsung pembaca membaca karangannya sendiri.

Tarigan (2015) menyatakan "minat membaca merupakan kemampuan seseo-rang berkomunikasi dengan diri sendiri untuk menangkap makna yang terkandung dalam tulisan sehingga memberikan pengalaman emosi akibat dari bentuk perhatian yang mendalam terhadap makna bacaan". Orang yang mempunyai minat membaca yang kuat diwujudkannya dalam kesediaannya untuk mendapat bahan bacaan dan kemudian membacanya atas kesadarannya sendiri. Adapun Dalman (2013: 7) menyatakan ketika seseorang membaca karangan orang lain ia berperan sebagai seperti penulis, iamenemukan ide, gagasan, serta mengorganisasikan bacaan dari karangan yang dibaca. Secara singkat dapat dikatakan bahwa dalam kegiatan karang-mengarang, pengarang menggunakan bahasa tulis untuk menyatakan isi hari dan ide secara menarik kepada pembaca. Pembaca bisa menuangkan ide dan gagasan dalam sebuah tulisan berupa cerita pendek. Cerita pendek (cerpen) adalah karangan fiksi singkat, sederhana, dan berisi masalah yang relative sederhana dibandingkan dengan novel (Nurhadi, 2016: 94). Dalam membuat cerpen banyak faktor yang mempengaruhi, seperti faktor instrinsik dan ekstrinsik dalam cerita pendek. Tampilan dan isi cerpen singkat dan sederhana. Oleh karena singkat dan sederhana, jumlah tokoh yang dihadirkan juga terbatas.

Cerita pendek (cerpen) adalah kara-ngan fiksi singkat, sederhana, dan berisi masalah yang relative sederhana dibandingkan dengan novel (Nurhadi, 2016: 94). Dalam membuat cerpen banyak faktor yang mem-pengaruhi, seperti faktor instrinsik dan eks-trinsik dalam cerita pendek. Tampilan dan isi cerpen singkat dan sederhana. Oleh karena singkat dan sederhana, jumlah tokoh yang dihadirkan juga terbatas.

Berdasarkan hasil wawancara dengan guru kelas V SD Gugus VII Mengwi, guru belum mengetahui faktor lain yang mempe-ngaruhi minat membaca siswa dan siswa kelas $\mathrm{V}$ SD Gugus VII dalam keterampilan menulis masih perlu ditingkatkan. Pemilihan sekolah dasar di Kecamatan Mengwi sebagai lokasi penelitian dengan alasan sekolah-sekolah tersebut berstatus negeri yang secara umum memiliki fasilitas yang mema-dai, seperti gedung sekolah yang bagus, tersedianya perpustakaan sekolah, pengajar yang cukup dan letak sekolah yang dekat dengan pusat kota. Hal ini memudahkan siswa untuk mengakses informasi sehingga bisa memiliki wawasan yang luas.

Tujuan dari penelitian ini adalah untuk mengetahui hubungan yang signifikan antara minat membaca dengan keterampilan menu-lis cerita pendek siswa kelas V SD Gugus VII Mengwi Tahun Ajaran 2017/2018.

\section{Metode}

Penelitian ini merupakan penelitian ex post facto dengan studi korelasional. Menurut Kerlinger (dalam Emzir, 2015:119) "penelitian ex post facto adalah penyelidikan empiris yang sistematis dimana ilmuan tidak mengen-dalikan variabel bebas secara langsung karena eksistensi dari variabel tersebut telah ter-jadi, atau karena variabel tersebut pada dasarnya tidak dapat dimanipulasi". "Dua buah gejala dikatakan mempunyai korelasi adalah apabila setiap perubahan pada gejala yang satu selalu diikuti dengan perubahan pada gejala yang lain, di mana masing-masing perubahan tersebut terjadi secara proporsional". Kesimpulannya yaitu, korelasi merupakan bentuk analisis data dengan menganalisis -

dua buah variabel yang memiliki hubungan -tmbal balik yang terjadi secara propor-sional. Variabel yang dimaksud adalah variabel bebas dan variabel terikat. Variabel bebas dalam 
penelitian ini adalah minat membaca, sedangkan variabel terikat dalam penelitian ini adalah keterampilan menulis cerita pendek.

Penelitian ini dilaksanakan di Gugus VII Mengwi yang terdiri dari 8 sekolah. Kedelapan sekolah tersebut adalah SD No. 1 Mengwitani, SD No. 2 Mengwitani, SD No. 3 Mengwitani, SD No. 4 Mengwitani, SD No. 5 Mengwitani, SDNo. 1 Kekeran, SD No. 2 Kekeran, SD No. 3 Kekeran. Populasi dari penelitian ini merupakan siswa kelas V SD Gugus VII Mengwi yang terdiri dari 186 siswa. Dalam penentuan sampel dapat dilihat pada tabel Issac and Michael. Dalam tabel tersebut dijelaskan tentang besarnya sampel yang diambil dari populasi dengan tingkat signifikansi $1 \%, 5 \%$, dan $10 \%$. Sesuaidengan tabel tersebut, dengan jumlah populasi di SD Gugus VII Mengwi sebanyak 186 siswa, jadi jumlah sampel yang diambil dengan tingkat signifikansi 5\% adalah123 siswa dari masing-masing sekolah sesuai dengan proporsi jumlah siswa dalam satu kelas.

Jumlah sampel pada SD No 1 Mengwitani yaitu sejumlah 27 siswa, jumlah sampel pada SD No 2 Mengwitani yaitu sejumlah 10 siswa, jumlah sampel pada SD No 3 Mengwitani yaitu sejumlah 10 siswa, jumlah sampel pada SD No 4 Mengwitani yaitu sejumlah 22 siswa, jumlah sampel pada SD No 5 Mengwitani yaitu sejumlah 13 siswa, jumlah sampel pada SD No 1 Kekeran yaitu sejumlah 6 siswa, Jumlah sampel pada SD No 2 Kekeran yaitu sejumlah 21 siswa, Jumlah sampel pada SD No 3 Kekeran yaitu sejumlah 15 siswa. Jadi total jumlah sampel yang diambil dari populasi berjumlah 123 siswa.

Pengambilan sampel menggunakan teknik sampling. Teknik sampling merupakan cara yang digunakan untuk menentukan sam-pel yang data dan objeknya menjadi representasi populasi. "Salah satu syarat utama dari sampel yang baik adalah bahwa sampel itu harus mengandung atau memiliki ciri-ciri ataupun sifat-sifat yang terdapat pada populasi" (Netra, 1974:10). Prosedur yang ditempuh dilakukan dengan jalan menentu-kan individu yang terdapat dalam masing-masing kategori populasi, sesuai dengan proporsi untuk dijadikan sampel penelitian. Populasi yang berjumlah 186 orang terdiri dari sembilan kategori atau kelas, maka teknik pengambilan sampel yang digunakan adalah teknik proporsional random sampling yang dilakukan dengan cara random (acak) menggunakan undian nomor absen siswa.

Pengumpulan data dalam penelitian ini meliputi data tentang keterampilan menulis cerita pendek dan minat membaca. Setyosari (2015: 247), "prosedur pengumpulan data ini menuturkan bagaimana data itu diperoleh". Jadi metode pengumpulan data adalah cara yang digunakan untuk memperoleh data. Pengumpulkan data yang diperoleh dalam penelitian ini yaitu metode tes dengan instrument tes uraian dan metode non-tes dengan instrument angket (kuesioner).

Tes dimaksudkan untuk memperoleh data tentang keterampilan menulis cerita pendek siswa kelas V SD dengan instrument yang digunakan berupa tes uraian. Data yang dimaksudkan disini adalah data kuantitatif yang berbentuk angka-angka atau skor. Menurut Suharsimi (2012: 67) tes merupakan alat atau prosedur yang digunakan untuk mengetahui atau mengukur sesuatu dalam suasana, dengan cara dan aturan-aturan yang sudah ditentukan untuk mengerjakan tes ini tergantung dari petunjuk yang diberikan.

Metode non-tes yang dimaksud dalam penelitian ini untuk memperoleh data tentang minat membaca. Dengan menggunakan instrument berupa angket (kuesioner). "Angket adalah teknik pengumpulan data yang dilakukan dengan cara memberi seperangkat pertanyaan atau pernyataan tertulis kepada responden untuk dijawabnya" (Sugiono, 2015: 199).

Data minat membaca dikumpulkan menggunakan kuesioner (angket). Bentuk angket yang digunakan adalah angket berstuktur dengan bentuk jawaban tertutup yang jawabannya telah tersedia dan responden menjawab setiap pertanyaan dengan cara memilih alternatif jawaban yang telah disediakan. "Angket atau kuesioner dikatakan menggunakan item tertutup, apabila peneliti dalam hal ini menyediakan beberapa alternatif jawaban, yang cocok bagi responden" (Sukardi, 2016:77). Kuesioner (angket) tersebut terdapat pernyataandengan masing-masing 4 pilihan yaitu Sangat Setuju (SS), Setuju (S), Tidak Setuju (TS) dan Sangat Tidak Setuju (STS). 
Pernyataan yang terdapat pada kuesioner sebanyak 30 pernyataan yang sesuai dengan kisi-kisi yang telah ditetapkan. Pengujian instrumen minat membaca yaitu menggunakan uji validitas diantaranya validitas logis dan empirik dan uji reliabilitas.

Bentuk tes yang digunakan pada penelitian ini yaitu dengan pemberian tugas kepada siswa untuk membuat karya tulis, dalam hal ini tulisan cerita pendek berdasarkan rangsang gambar. Media yang digunakan dalam tugas menulis cerita pendek berupa gambar seri. Setelah data minat membaca dengan keterampilan menulis cerita pendek diperoleh, dilanjutkan dengan menganalisis data hasil penelitian.

Teknik analisis data yang digunakan dalam penelitian ini yaitu analisis statistik deskriptif dan analisis statistik inferensial. Pada statistik deskriptif juga dapat dilakukan mencari kuatnya hubungan antara variabel melalui analisis korelasi. Agung (2014) menyatakan pengolahan data pada analisis statistik deskriptif dilakukan dengan menggunakan rumus seperti: distribusi frekuensi, grafik, angka rata-rata, median, modus, mean dan standar deviasi, untuk menggambarkan suatu objek/variabel tertentu. Analisis statistik deskriptif pada penelitian ini menggunakan rata-rata (mean), median dan standar deviasi.

Metode analisis statistik inferensial yang dilakukan adalah menguji hipotesis. Uji hipotesis ini dilakukan setelah mendapatkan data tentang minat membaca dan keterampi-lan menulis cerita pendek. Untuk memenuhi persyaratan pengujian hipotesisnya, diperlu-kan persyaratan analisis yaitu uji normalitas sebaran data. Setelah data berdistribusi normal dilanjutkan dengan analisis statistik inferensial menggunakan teknik korelasi product moment.

Adapun hipotesis yang diuji yaitu hipotesis nol $\left(H_{0}\right)$ yang berbunyi tidak terdapat hubungan yang signifikan antara minat membaca dengan keterampilan menu-lis cerita pendek siswa kelas V SD Gugus VII Mengwi Tahun ajaran 2017/2018. Ketentuan dari analisis product moment yang digunakan yaitu apabila hasil $r_{x y \text { hitung }}>r_{x y t a b e l}$ maka $\left(H_{0}\right)$ yang berbunyi tidak terdapat hubungan yang signifikan antara minat membaca dengan keterampilan menulis cerita pendek siswa kelas V SD Gugus VII Mengwi Tahun Ajaran 2017/2018 ditolak dan hipotesis alter-natif $\left(H_{a}\right)$ yang berbunyi terdapat hubungan yang signifikan antara minat membaca dengan keterampilan menulis cerita pendek siswa kelas V SD Gugus VII Mengwi Tahun Ajaran 2017/2018 diterima. Sebaliknya apa-bila hasil $r_{x y \text { hitung }} \leq r_{x y \text { tabel }}$ maka $H_{0}$ diterima dan $H_{a}$ ditolak.

\section{Hasil dan Pembahasan}

Hasil penelitian ini memaparkan mengenai data minat membaca sebagai variabel bebas $(\mathrm{X})$ dan keterampilan menulis cerita pendek sebagai variabel terikat ( $\mathrm{Y}$ ) yang ditampilkan grafik. Data minat membaca dapat dilihat dalam bentuk grafik berikut.



Gambar 1. Histogram Data Minat Membaca

Data minat membaca dapat diketahui bahwa nilai tertinggi $(X t)=93$, nilai terendah $(X r)$ $=59$ dan standar deviasi $(\mathrm{s})=8,25$, serta rerata dari nilai sikap komunikatif siswa adalah 
74,89 dan nilai tersebut berada pada nilai PAP rentang 65-79. Maka dapat disim-pulkan bahwa sikap komunikatif siswa kelas V SD di Gugus VII Mengw tergolong cukup baik.

Kemudian data dari keterampilan menulis cerita pendek dapat dilihat dalam bentuk grafik berikut.

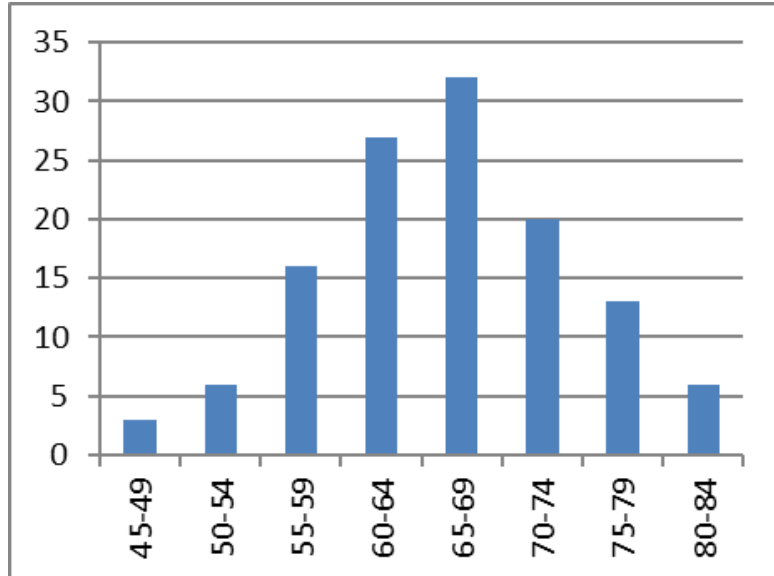

Gambar 2. Histogram Data Keterampilan Menulis Cerita Pendek

Berdasarkan hasil analisis keteram-pilan menulis cerita pendek diketahui bahwa bahwa nilai tertinggi $(X t)=82$, nilai terendah $(X r)=45$ dan standar deviasi $(s)=8,02$, serta rerata dari nilai ilmu pengetahuan IPS siswa adalah 65,98 dan nilai tersebut berada pada nilai PAP rentang 65-79. Maka dapat disim-pulkan bahwa keterampilan menulis cerita pendek siswa kelas V SD Gugus VII Mengwi tergolong cukup kreatif.

Langkah selanjutnya adalah uji prasya-rat yaitu Uji Normalitas minat membaca dan keterampilan menulis cerita pendek siswa kelas V SD Gugus VII Mengwi menggunakan teknik uji Chi-Kuadrat $\left(x^{2}\right)$.

Hasil uji minat membaca yaitu berda-sarkan analisis diperoleh $x_{\text {hitung }}^{2}=4,07$, dan menggunakan taraf signifikan $5 \%$ diperoleh $x_{\text {tabel }}^{2}=11,07$ maka, $x_{\text {hitung }}^{2}=4,07<x_{\text {tabel }}^{2}=$ 11,07. Hal ini berarti $H_{0}$ diterima, sehingga dapat disimpulkan bahwa sebaran data berdistribusi normal.

Hasil uji normalitas keterampilan me-nulis cerita pendek siswa kelas V SD Gugus VII Mengwi yaitu berdasarkan analisis dipe-roleh $x_{\text {hitung }}^{2}=2,76$, dan menggunakan taraf signifikan $5 \%$ diperoleh $x_{\text {tabel }}^{2}=11,07$ maka, $x_{\text {hitung }}^{2}=3,49<x_{\text {tabel }}^{2}=11,07$. Hal ini berarti $\mathrm{H}_{0}$ diterima, sehingga dapat disimpulkan bahwa sebaran data berdistribusi normal.

Setelah melalui uji normalitas dan data berdistribusi normal maka dilanjutnya dengan uji hipotesis yang dilakukan adalah uji hipotesis dengan teknik menggunakan ana-lisis product moment (variabel $\mathrm{X}$ dengan $\mathrm{Y}$ ). "Teknik korelasi Product Moment berfungsi untuk menghitung koefisien korelasi antara variabel bebas interval (skor) dengan variabel terikat interval (skor) lainnya" (Agung, (2014:125). Adapun langkah-langkah analisis korelasi product moment adalah sebagai berikut.

1) Menentukan hipotesis nol

2) Menyusun tabel kerja statistik

3) Memasukkan data hasil kerja statistik ke dalam rumus

4) Menguji harga statistik hasil penelitian

5) Menarik kesimpulan

Hipotesis nol $\left(\mathrm{H}_{0}\right)$ yang dirumuskan pada penelitian ini berbunyi tidak terdapathubungan yang signifikan antara minat membaca dengan keterampilan menulis cerita pendek siswa kelas V SD Gugus VII Mengwi tahun ajaran 2017/2018. Rumus yang digunakan pada korelasi product moment adalah sebagai berikut. 


$$
r_{x y}=\frac{N \sum X Y-\left(\sum X\right)\left(\sum Y\right)}{\sqrt{\left[N \sum X^{2}-\left(\sum X\right)^{2}\right]\left[N \sum Y^{2}-\left(\sum Y\right)^{2}\right]}}
$$

(Suharsimi, 2012: 87)

Keterangan:

$\begin{array}{ll}r_{x y} & : \text { koefisien korelasi antara } \\ N & : \text { Jumlah Subjek } \\ X & : \text { Skor item } \\ Y & : \text { Skor total } \\ \sum X & : \text { Jumlah skor item } \\ \sum Y & : \text { Jumlah skor total } \\ \sum X^{2} & : \text { Jumlah kuadrat skor item } \\ \sum Y^{2} & \text { : Jumlah kuadrat skor total }\end{array}$

X sebagai data-data dari variabel independent (variabel bebas)

Y sebagai data-data dari variabel dependent (variabel terikat).

Hasil analisis product moment bisa dilihat pada tabel 1 .

Tabel 1. Analisis Product Moment

\begin{tabular}{cc}
\hline$\sum X$ & 9223 \\
\hline$\sum Y$ & 8104 \\
\hline$\sum X^{2}$ & 699731 \\
\hline$\sum Y^{2}$ & 542104 \\
\hline$\sum X Y$ & 611586 \\
\hline$r_{x y \text { hitung }}$ & 0,480 \\
\hline$r_{x y}$ tabel & 0,176 \\
\hline
\end{tabular}

Untuk uji signifikansi koefisien korelasi, digunakan nilai tabel product moment $(\mathrm{r})$ untuk $\mathrm{n}$ $=123$, pada taraf signifikansi $5 \%$ diperoleh nilai $r_{x y}$ tabel adalah 0,176 sedangkan $r_{x y}$ hitung diperoleh hasil 0,480. Maka dapat dinyatakan $r_{x y \text { hitung }}=0,480>r_{x y \text { tabel }}=0,176$.

Berdasarkan hasil analisis penelitian yang diperoleh yaitu $r_{x y}$ huitung $>r_{x y}$ tabel sehingga $\mathrm{H}_{0}$ yang berbunyi tidak terdapat hubungan yang signifikan antara minat membaca dengan keterampilan menulis cerita pendek siswa kelas V SD Gugus VII Mengwi Tahun Ajaran 2017/2018 ditolak sedangkan Ha yang berbunyi terdapat hubungan yang signifikan antara minat membaca dengan keterampilan menulis cerita pendek siswa kelas V SD Gugus VII Mengwi Tahun Ajaran 2017/2018 diterima. Berdasarkan uraian tersebut dapat mengemukakan interpretasi, berarti bahwa rata-rata siswa yang tergolong memiliki minat membaca, siswa akan memperoleh nilai yang lebih tinggi dalam menulis serta memiliki wawasan yang luas dan minat yang tinggi dalam menulis cerita pendek.

Semakin tinggi minat membaca sese-orang, semakin sering pula kegiatan mem-baca yang dilakukannya. Semakin sering kegiatan membaca dilakukan, semakin ba-nyak pengetahuan yang dimilikinya. Semakin banyak pengetahuan yang dimiliki semakin mudah menemukan ide dan mengembang-kan ide tersebut yang pada akhirnya memba-ntu penulis untuk semakin terampil dalam menulis, khususnya menulis cerita pendek. Menulis membutuhkan bahan/materi tulisan dan membutuhkan penguasaan perbendaharaan kata yang banyak sehingga memudah-kan bagi penulis untuk menyampaikan apa yang dipikirkannya. Selain itu dalam menulis juga terdapat aturan yang berlaku agar tulisan layak untuk dibaca oleh orang lain. Ide tulisan tidak datang tiba-tiba tanpa adanya pengetahuan yang dimiliki oleh si penulis. Membaca menjadi salah satu jalan untuk seseorang menemukan dan bisa mengem-bangkan ide sesuai dengan tujuan yang hendak dicapai. Membaca yang dimaksud disini tidak hanya melafalkan simbol-simbol tulisan. 
Namun siswa juga harus memahami apa yang dibacanya, mencermati bagaimana tulisan itu terbentuk, menghafalkan kosa kata baru sehingga menambah perbendaharaan kata.

Hal ini juga didukung oleh penelitian Maryuningsih (2014) yang menyatakan berdasarkan hasil analisis data diperoleh $t_{\text {hitung }}$ sebesar 0,555 . Dengan taraf signifikansi $5 \%$ itu menunjukkan $\mathrm{Ha}$ diterima. Dapat diinterpretasikan bahwa terdapat perbedaan yang signifikan minat membaca dengan keterampilan menulis narasi siswa kelas IV sekolah dasar se-gugus Kecamatan Kraton Yogyakarta tahun ajaran 2013/2014.

Pada penelitian ini dperoleh $r_{x y}$ hitung $=0,480$ dengan $r_{x y}$ tabel pada taraf signifikan $5 \%$ adalah $\mathrm{n}=123$. Nilai $r_{x y \text { tabel }}$ untuk $\mathrm{n}=123$ adalah 0,176 . Hal ini berarti $r_{x y}$ hitung $>r_{x y}$ tabel yang berarti terdapat hubungan yang positif antara minat membaca dengan keterampilan menulis cerita pendek. Walaupun tergolong dalam kategori korelasi sedang, tetapi pengembangan minat membaca dalam diri siswa harus diterapkan karena juga akan berdampak pada keterampilan menulis siswa.

Sebagai implikasi dari hasil penelitian ini dalam melaksanakan kegiatan pembelajaran, utamanya dalam menumbuhkan minat membaca siswa. Maka secara teoritis, keterampilan menulis cerita pendekditentukan` oleh beberapa faktor, salah satunya adalah minat membaca. Hal ini berarti agar dapat memiliki keterampilan menulis cerita pendek yang baik, diperlukan minat membaca yang baik. Dengan adanya implikasi teoritis perlu adanya implikasi praktis yang merupakan kebijakan yang berupa usaha-usaha nyata agar dapat meningkatkan keterampilan menulis cerita pendek siswa. Usaha-usaha yang dilakukan adalah dengan meningkatkan minat membaca yang memiliki hubungan yang positif yang signifikan dengan keterampilan menulis cerita pendek.

Ada berbagai upaya yang dapat dilakukan oleh guru dalam meningkatkan minat membaca siswa antara lain:

1) Selalu memotivasi siswa tentang minat membaca.

2) Membudayakan kegiatan membaca.

3) Menyediakan bahan bacaan yang bervariasi jenisnya.

4) Memperbaiki koleksi buku-buku diperpustakaan serta menyusun buku-buku tersebut dengan baik.

5) Menerapkan metode yang bervariatif. Contohnya guru memberikan tugas untuk menceritakan salah satu buku yang dibacanya di depan kelas secara bergantian.

\section{Simpulan dan Saran}

Hasil analisis menunjukkan bahwa terdapat hubungan yang signifikan antara minat membaca dengan keterampilan menu-lis cerita pendek Kelas V SD Gugus VII Mengwi Tahun Ajaran 2017/2018. Katagori hubungan yang diperoleh termasukhubungan yang sedang antara minat membaca dengan keterampilan menulis cerita pendek. Sedang-kan arah korelasi adalah positif karena nilai $r$ positif, berarti semakin tinggi minat membaca siswa maka semakin tinggi pula hasil keterampilan menulis cerita pendek siswa.

Berdasarkan hasil analisis dengan menggunakan microsoft excel dan menghitung manual yang diperoleh $r_{x y}$ hitung $=0,480$ dengan $r_{x y \text { tabel }}=0,176$ yang memiliki arti $r_{x y}$ hitung $>r_{x y}$ tabel, sehingga $\mathrm{H}_{0}$ yang berbunyi tidak terdapat hubungan yang signifikan antara minat membaca dengan keterampilan menulis cerita pendek siswa kelas V SD Gugus VII Mengwi Tahun Ajaran 207/2018 ditolak, sedangkan Ha yang berbunyi terdapat hubungan yang signifikan antara minat membaca dengan keterampilan menulis cerita pendek siswa kelas $\mathrm{V}$ SD Gugus VII Mengwi Tahun Ajaran 207/2018 diterima.

Berdasarkan uraian tersebut dapat mengemukakan interpretasi, maka ini berarti bahwa rata-rata siswa yang tergolong memi-liki minat membaca mampu meningkatkan keterampilan menulis cerita pendek siswa. Pengertian tersebut dapat diartikan, semakin tinggi minat membaca siswa, maka semakin tinggi pula nilai keterampilan menulis cerita pendek siswa. Jadi dapat disimpulkan terdapat hubungan yang signifikan antara minat membaca dengan keterampilan menulis cerita pendek siswa memiliki korelasi dengan arah positif pada kategori sedang. 
Berdasarkan temuan penelitian yang diperoleh, disarankan kepada guru agar dapat memberikan perhatian lebih dalam aktivitas membaca siswa, dengan harapan dapat meningkatkan keterampilan mereka dalam menulis cerita pendek. Perhatian guru bisa diwujudkan dengan memberikan hadiah kepada siswa bagi siswa yang gemar membaca. Hal ini dilakukan agar siswa lebih termotivasi untuk membaca.

Kepada kepala sekolah disarankan agar dapat menggunakan hasil penelitian ini sebagai pendukung sumber belajar guru da-lam meningkatkan kualitas pembelajaran dengan menumbuhkan minat membaca siswa di sekolah sehingga sekolah mampu menghasilkan siswa yang berkualitas.

Kepada peneliti lain disarankan agar hasil penelitian ini digunakan sebagai referensi untuk melaksanakan penelitian selanjut-nya atau menemukan inovasi untuk mening katkan pelaksanaan kegiatan pembelajaran yang bermakna dan mampu mengoptimalkan kemampuan siswa.

\section{Daftar Pustaka}

Penggunaan Media Film Animasi Terhadap Keterampilan Menulis Karangan Narasi Siswa Kelas V SD". Jurnal Prima Edukasia, Vol. 2, No. 2 (hlm. 251-253). Tersedia pada https://id.scribd.com/doc/200816283/1. Diakses pada 20 Januari 2018.

Dalman, H. 2013. Keterampilan Membaca. Jakarta: PT Rajagrafindo Persada.

Dalman, H.2016. Keterampilan Menulis. Jakarta: PT Rajagrafindo Persada.

Emzir. 2015. Metodologi Penelitian Pendidikan: Kuantitatif dan Kualitatif. Jakarta: PT RajaGrafindo Persada.

Maryuningsih. 2014. Hubungan Antara Minat Membaca dengan Keterampilan Menulis Narasi Siswa Kelas IV se-Gugus Kecamatan Kraton Yogyakarta Tahun Ajaran 2013/2014.

Yogyakarta: UNY. Tersedia pada

https://www.neliti.com/id/publications/135044/hubungan-minat-baca-dengan-

keterampilan-menulis-narasi-siswa-kelas-V . Diakses pada tanggal 20 Januari 2018.

Nurgiyantoro, Burhan. 2012. Penilaian Pembelajaran Bahasa Berbasis Kompetensi. Yogyakarta: BPFE

Nurhadi. 2016. Teknik Membaca. Jakarta: PT Bumi Aksara

Setyosari, Punaji. 2015. Metode Penelitian Pendidikan dan Pengembangan. Jakarta: Kencana .

Sugiyono. 2015. Metode Penelitian Pendidikan Pendekatan Kuantitaif, Kualitatif, dan R\&D. Bandung: Alfabeta

Sukardi. 2016. Metodologi Penelitian Pendidikan. Jakarta: PT Bumi Aksara.

Tarigan 2015. Membaca sebagai Suatu Keterampilan Berbahasa. Bandung: CV Angkasa.

Tim Redaksi. 2001. Kamus Besar Bahasa Indonesia. Pusat Bahasa Depdiknas. 